\title{
Keanekaragaman Jenis Ikan di Sungai Lempake Tepian Kecamatan Sungai Pinang Kota Samarinda
}

\author{
Sri Purwati', Masitah', Sinta Budiarti', Yeni Aprilia' \\ 'Program Studi Pendidikan Biologi FKIP Universitas Mulawarman, Samarinda, Indonesia \\ *purwati7504@gmail.com
}

\begin{abstract}
This study aims to determine the diversity of fish species in the Lempake Tepian River, Sungai Pinang sub-district, Samarinda City. The fish in this river are used for consumption by the community. Changes in river water quality have resulted in a decrease in the level of population and fish species in the river. Sampling was done by purposive sampling which was divided into 3 locations, namely the upstream, middle and downstream rivers. Based on the analysis of the diversity index data (H) 1,969 was categorized as moderate, the relative abundance of fish (29.8\%), broom fish $27.35 \%$, puyau (19.33\%), puyau fish (19.33\%), sepat fish (16.50\%) and tilapia. (7.07\%). The uniformity index (e) of 0.394 is categorized as moderate and the Dominance index (C) of fish species in the Lempake River Tepian Samarinda City is 0.04, it can be concluded that there are no species that dominate in the Lempake Tepian River Samarinda City.
\end{abstract}

Key words: diversity, fish, river

\begin{abstract}
Abstrak Penelitian ini bertujuan untuk mengetahui keanekaragaman jenis ikan di Sungai Lempake Tepian kecamatan Sungai pinang Kota Samarinda. Ikan-ikan di Sungai ini digunakan dikonsumsi oleh masyarakat. Perubahan kualitas air sungai menyebabkan adanya penurunan tingkat populasi dan spesies ikan di sungai tersebut. Pengambilan sampel secara purposive sampling yang dibagi menjadi 3 lokasi yakni sungai bagian hulu, tengah dan hilir. Berdasarkan analisis data indeks keanekarangan (H) 1.969 dikategorikan sedang, kemelimpahan relatif ikan seluang (29.8\%), ikan sapu-sapu $27.35 \%$, puyau (19.33\%), ikan puyau (19.33\%), ikan sepat (16.50\%) dan ikan nila (7.07\%). Indeks keseragaman (e) sebesar 0.394 dikategorikan sedang dan indeks Dominansi (C) jenis ikan di Sungai Lempake Tepian Kota Samarinda sebesar 0.04 maka dapat disimpulkan tidak ada spesies yang mendominasi di Sungai Lempake Tepian Kota Samarinda.
\end{abstract}

Kata kunci: keanekaragaman, ikan, sungai

Penerbit

Program Studi Pendidikan Biologi, Fakultas Keguruan dan Ilmu Pendidikan, Universitas Mulwarman, Samarinda, Kalimantan Timur, Indonesia

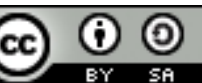

This Jurnal Ilmiah Biosmart (JIBS) is licensed under a CC BY-SA (Creative Commons AttributionShareAlike 4.0 International License) 


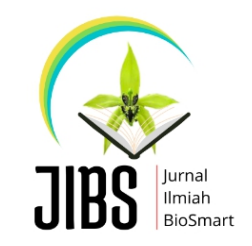

\author{
JURNAL ILMIAH BIOSMART (JIBS) \\ Volume 1, Nomor 1 \\ p-ISSN: 2356-1823 \\ https://jurnal.fkip.unmul.ac.id/index.php/biosmart
}

\title{
PENDAHULUAN
}

Air adalah zat atau materi atau unsur yang penting bagi semua bentuk kehidupan yang diketahui sampai saat ini di bumi, tetapi tidak di planet lain dalam sistem tata surya dan menutupi hampir $71 \%$ permukaan bumi, wujudnya bisa berupa cairan, es (padat) dan uap atau gas. Air adalah semua air yang terdapat di atas ataupun di bawah permukaan tanah, air hujan dan air laut yang berada di darat (Kodoatie, 2010; Andawayanti, 2019).

Air merupakan sumber daya alam yang sangat bermanfaat untuk makhluk hidup. Manusia menggunakan air untuk memenuhi berbagai kebutuhan sehari-hari diantaranya seperti keperluan rumah tangga, pertanian, industri dan sebagainya. Peranan air begitu penting dalam kehidupan manusia, sehingga perlu untuk mengupayakan dalam menjaga kualitas sumber air dan sungai untuk keberlangsungan dimasa depan.

Masyarakat di Kota Samarinda sebagian tinggal di sekitar anak sungai Mahakam. Berdasarkan observasi dan wawancara, masyarakat berpendapat jika hidup dekat dengan sungai dan sekitarnya mudah untuk memenuhi kebutuhan seperti mencuci, mandi, memasak, mencari ikan, memudahkan aktivitas pertanian, dan lain-lain. Aktivitas mencari ikan masih dilakukan oleh warga sekitar Sungai Lempake Tepian untuk dikonsumsi dan sebagian lagi dijual. Hasil observasi air Sungai lempake Tepian berkondisi bewarna keruh, dan memang masih meunjukkan adanya biota di dalamnya seperti ikan dan lobster air tawar. Sampah-sampah masih mudah. Saat ini ikan cukup sulit untuk diperoleh seiring dengan perkembangan dan perluasan daerah perkotaan. Perluasan pemukiman penduduk di Kota Samarinda, khususnya di Desa Lempake juga diringi dengan peningkatan aktivitas masyarakatnya seperti pasar, sekolah, puskesmas, perkantoran serta lahan pertanian memberikan perubahan pada lingkungan perairan kawasan sungai. Aktivitas masyarakat juga memberikan dampak seperti meningkatnya sampah dan bahan buangan yang mengalir ke sungai. Aktivitas tersebut tentunya mengahasilkan bahan buangan seperti limbah domestik, limbah pertanian, limbah industri kecil dan menengah serta limbah pada kawasan Perusahan Air Minum menambah kekeruhan air yang mempengaruhi kehidupan biota di sungai, 

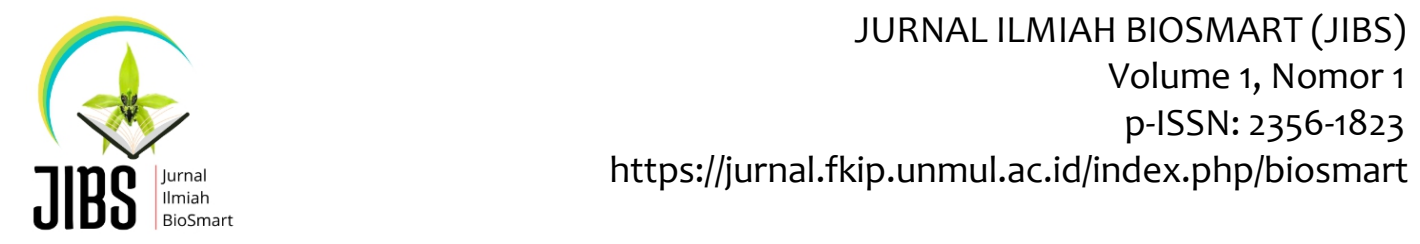

terutama ikan air tawar.

Menurut Alamsyah (2006) secara fisik, air sungai terlihat berwarna coklat dengan tingkat kekeruhan yang tinggi karena bercampur dengan pasir, lumpur, kayu dan kotoran lainnya. Kualitas air sungai juga dipengaruhi oleh lingkungan di sekitar aliran sungai. Secara umum, kualitas air sungai di daerah hilir (muara) lebih rendah dibandingkan di daerah hulu (mata air). Hal ini terjadi akibat limbah industri dan rumah tangga yang dibuang langsung ke sungai tanpa melalui proses pengolahan terlebih dahulu terkumpul di muara sungai.

Air yang tersedia di bumi memang tidak akan pernah habis. Namun permasalahan yang serius dapat terjadi ketika adanya kegagalan dalam memenuhi kebutuhan manusia terhadap akses air bersih dan sanitasi, karena kekurangan dan kelangkaan air. Hal ini dapat terjadi karena beberapa hal, antara lain akibat terkontaminasinya air dari limbah domestik, limbah industri, bencana banjir dan kekeringan ataupun akibat pemanasan global yang menggangu siklus hidrologi dan manejemen air (Gleick dan Palaniapan, 2010).

Selain sungai memenuhi kebutuhan akan air, masyarakat yang hidup di bantaran sungai seringkali mencari ikan-ikan di sungai tersebut untuk dikonsumsi. Sebagian masyarakat menggunakan perahu untuk memancing dan menjala untuk menangkap ikan. Mereka juga menjual hasil tangkapan selain untuk dikonsumsi keluarga. Fenomena ini pula terjadi pada sebagian masyarakat di Kota Samarinda khususnya di Sungai Lempake Tepian.

Sungai adalah air yang mengalir pada permukaan bumi yang terbentuk secara alami dan membentuk suatu pola aliran air. bagian hulu Sungai umumnya terletak di kawasan perbukitan dan kawasan pegunungan. Aliran sungai mengalir dari daerah yang tinggi yang disebut hulu dan berakhir pada suatu lokasi di daerah yang lebih rendah biasanya disebut hilir, sungai bermanfaat sebagai salah satu sumber air bagi makhluk hidup dan selalu berhubungan dengan perkembangan zaman (Juwono, 2019: 15).

Menurut (Mukti, 2017), berdasarkan data dari Badan Lingkungan Hidup Kota Samarinda diketahui bahwa dari tahun 2010 hingga 2017 kualitas air sungai karang mumus telah tercemar berat. Sungai Mahakam yang membentang melalui Kabupaten 


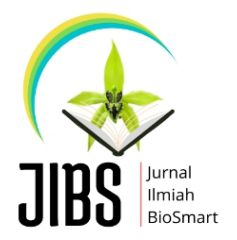

JURNAL ILMIAH BIOSMART (JIBS)

Volume 1, Nomor 1

p-ISSN: 2356-1823

https://jurnal.fkip.unmul.ac.id/index.php/biosmart

Mahakam Ulu, Kutai Barat, Kutai Kartanegara dan Samarinda menuju ke pesisir Muara Jawa (getborneo.com dalam Nala, 2020). Sungai Mahakam memiliki anakan sungaisungai kecil. Salah satu anak sungai Mahakam yang termasuk sungai kecil adalah Sungai 9 Karang Mumus. Sungai Karam Mumus berada di tengah Kota Samarinda. Sungai Karam Mumus memiliki panjang aliran 34,7 kilometer (Afriani, 2020).

Adanya perluasan perubahan kawasan menjadi lahan tambang dan pemukiman penduduk disekitar bentangan sungai Lempake Tepian tersebut menyebabkan hujan membawa material lumpur, partikel-partikel pasir, tanah yang hanyut ke sungai dan menyebabkan pendangkalan sungai. Peningkatan sedimentasi ini tentu berpengaruh pada kehidupan populasi jenis-jenis ikan air tawar. Perubahan dinamika kehidupan masyarakat di area perkotaan khususnya di Lempake dan sekitarnya berdampak pada kecenderungan menurunnya populasi ikan, selain menurunnya jenis-jenis ikan tersebut.

Ikan merupakan salah satu sumber asam lemak tak jenuh dan protein hewani terbaik. Protein pada ikan terdiri atas asam amino yang tidak rusak saat pemanasan. Kandungan protein pada ikan bervariasi, tergantung kandungan lemak dan airnya. Secara umum ikan mengandung $13-20 \%$ protein yang dapat membantu pertumbuhan sel otak. Protein ikan mudah dicerna bahkan oleh bayi sekalipun. Ikan juga merupakan sumber kalsium, terutama pada ikan teri (Murdiati, 2013).

Dibandingkan dengan negara lain, konsumsi ikan per kapita per tahun di Indonesia saat ini masih tergolong rendah, yaitu 19,14 kg. Hal ini sangat disayangkan, terutama mengingat betapa besar peranan gizi ikan bagi kesehatan. Kandungan gizi ikan air tawar cukup tinggi dan hampir sama dengan ikan air laut, sehingga dianjurkan dikonsumsi dalam jumlah yang 10 cukup (Erwin, 2011). Menurut Permenkes RI, 2019 dalam Wulandari, 2020), rata-rata angka kecukupan protein bagi masyarakat Indonesia sebesar 57 (lima puluh tujuh) gram per orang per hari pada tingkat konsumsi.

Menurunnya kualitas ekosistem perairan akan berdampak pada jaringan kehidupan, sehingga berpengaruh pada mata rantai ekosistem dan menurunkan populasi ikan. Diduga ikan melakukan adaptasi dengan perubahan air, melakukan regulasi respirasi maupun osmosis yang menyebabkan sebagian ikan tidak mampu 


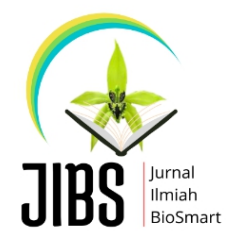

JURNAL ILMIAH BIOSMART (JIBS)

Volume 1, Nomor 1

p-ISSN: 2356-1823

https://jurnal.fkip.unmul.ac.id/index.php/biosmart

untuk mendiami perairan tersebut. Sebagian ikan cenderung akan berdistribusi berpindah ke tempat yang lebih layak untuk dihuni, dan sebagian jenis lagi tidak mampu mendiami lingkungan yang ekstrim. Oleh karenanya terjadi penurunan jumlah populasi dan berkurangnya jenis ikan. Fenomena ini tidak hanya berpengaruh pada jenis ikan tapi berpengaruh pada biota lain seperti lobster air tawar, udang dan biota lain.

\section{METODE PENELITIAN}

Jenis penelitian ini adalah deskriptif yakni menggambarkan situasi dan kondisi sebenarnya berdasarkan data-data hasil penelitian. Penelitian ini merupakan penelitian yang mengambil data langsung di lapangan yang berupa berbagai jenis ikan yang ditemukan dalam di Sungai Lempake Tepian Kecamatan Sungai Pinang Kota Samarinda. Data diperoleh dari penelitian setelah berdiskusi dengan tim peneliti untuk meninjau langsung ke lokasi dan dilakukan wawancara dengan masyarakat setempat. Penelitian ini dilaksanakan di Sungai Lempake Tepian Kecamatan Sungai Pinang Kota Samarinda. Adapun penelitian ini dibagi menjadi 3 lokasi yakni lokasi hulu, tengah dan hilir. Pembagian lokasi dilakukan oleh tim peneliti menggunakan perahu dan memperkirakan jarak lokasi sepanjang aliran sungai. Teknik pengambilan sampel dilakukan perdasarkan purposive sampling yakni berdasarkan pertimbangan tertentu. Pertimbangan tersebut diantaranya mengumpulkan ikan yang terjaring atau terpancing di lokasi penelitian. Pengumpulan ikan juga dilakukan secara bertahap dalam beberapa hari dengan mempertimbangkan pagi, siang dan sore hari, cuaca dan musim.

Observasi lapangan dilakukan selama kegiatan penelitian. Observasi awal dilakukan untuk memperoleh data-data awal, melihat langsung kondisi dan suasa ekologi disepanjang Sungai Lempake Tepian. Mengamati aliran sungai hingga muara, kondisi aktivitas fisik dan sosial masyarakat yang mempengaruhi kondisi air sungai.

Wawancara dilakukan kepada sebagian masyarakat Desa Lempake khususnya yang mendiami pemukiman disekitar bantaran sungai. Dari wawancara ini dapat diperoleh data-data, fakta dan keterkaitan aktivitas manusia dengan kondisi ekologis sungai. Melihat faktor-faktor yang diduga mempengaruhi kondisi sungai yang 


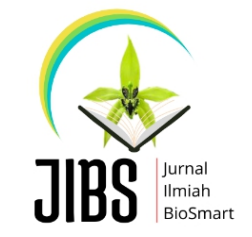

JURNAL ILMIAH BIOSMART (JIBS)

Volume 1, Nomor 1

p-ISSN: 2356-1823

https://jurnal.fkip.unmul.ac.id/index.php/biosmart

dikaitkan dengan biota-biota. Dokumentasi dilakukan untuk memperoleh data dan fakta yang terjadi di lapangan. Semua aktivitas kegiatan penelitian ini dilakukan dokumentasi agar dapat menyimpan atau merekam hasil penelitian selama kegiatan berlangsung.

Teknik analisis data pada penelitian ini dilakukan secara deskriptif yakni menjabarkan hasil penelitian yang diperoleh. Data selanjutnya diolah untuk mengetahui Kelimpahan Relatif (KR), Indeks Keanekaragaman ( $H^{\prime}$ ) dan Indeks Keseragaman (e) serta Indeks Dominansi (C). Menurut Kusumaningsari dkk (2015) untuk mengetahui kemelimpahan, kelimpahan relatif, indeks keanekaragaman, indeks keseragaman dan dominansi dilakukan dengan memasukkan data hasil penelitian ke dalam rumus sebagai berikut:

1. Kelimpahan Relatif (KR)

Kelimpahan dihitung dengan menggunakan rumus dalam Odum (1993), yaitu:

$$
\mathrm{KR}=\frac{n i}{N} \times 100 \%
$$

Keterangan:

$\mathrm{KR}=$ Kelimpahan Relatif

$\mathrm{ni}=$ Jumlah individu spesies ke-i

$\mathrm{N}=$ Jumlah individu seluruh spesies

2. Indeks Keanekaragaman ( $\left.\mathrm{H}^{\prime}\right)$

Indeks keanekaragaman ( $\left.\mathrm{H}^{\prime}\right)$ menggambarkan keadaan populasi organisme secara matematis agar mempermudah dalam menganalisis informasi jumlah individu masing-masing jenis pada suatu komunitas. Untuk itu dilakukan perhitungan dengan menggunakan persamaan dari Shannon-Wienner (Krebs, 1989).

$$
\mathrm{H}^{\prime}=-\sum_{i=s}^{s} p i \ln p i
$$

Keterangan:

$\mathrm{H}^{\prime}=$ Indeks Keanekaragaman Shannon-Wiener

$\mathrm{ni}=$ Jumlah individu dari suatu jenis ke-i

$\mathrm{s}=$ Jumlah total individu seluruh jenis

$\mathrm{Pi}=\mathrm{ni} / \mathrm{N}=$ sebagai proporsi jenis ke-i 
JURNAL ILMIAH BIOSMART (JIBS)

Volume 1, Nomor 1

p-ISSN: 2356-1823

https://jurnal.fkip.unmul.ac.id/index.php/biosmart

3. Indeks Keseragaman (e)

Untuk mengetahui keseimbangan komunitas digunakan indeks keseragaman, yaitu ukuran kesamaan jumlah individu antar spesies dalam suatu komunitas. Semakin mirip jumlah individu antar spesies (semakin merata penyebarannya) maka semakin besar derajat keseimbangan. Indeks keseragaman (Evenness index) yang digunakan berdasarkan fungsi Shannon-Wiener untuk mengetahui sebaran tiap jenis hewan makrobentos dalam luasan area pengamatan (Fachrul, 2007).

$$
\mathrm{E}=\frac{H^{\prime}}{H \max }=\frac{\mathrm{H}^{\prime}}{\operatorname{In} S}
$$

Keterangan:

$\mathrm{E}=$ Indeks Kemerataan

$\mathrm{H}^{\prime}=$ Indeks Keanekaragaman

$\mathrm{H} \max =\ln \mathrm{S}$

$\mathrm{S}=$ Jumlah spesies

4. Dominansi (C)

Indeks Dominansi (C) Indeks Dominansi dihitung dengan menggunakan rumus indeks dominanasi dari Simpson (Odum, 1993): $\mathrm{D}=\Sigma(\mathrm{ni} / \mathrm{N}) 2$ Keterangan: $\mathrm{C}=$ Indeks Dominansi Simpson $\mathrm{Ni}=$ Jumlah Individu tiap spesies $\mathrm{N}=$ Jumlah Individu seluruh spesies.

$$
C=\sum_{i=1}^{n}\left[\frac{n_{i}}{N}\right]^{2}
$$

Keterangan:

$C=$ Indeks dominansi Simpson

$\mathrm{ni}=$ jumlah total individu jenis ke- $\mathrm{i}$

$\mathrm{N}=$ jumlah seluruh individu dalam total $\mathrm{n}$

\section{Hasil Penelitian dan Pembahasan}

Penelitian ini dilaksanakan di Sungai Lempake Tepian Samarinda. Penelitian ini dilakukan dengan meletakkan alat penangkap ikan (bubu) yang dibiarkan selama 


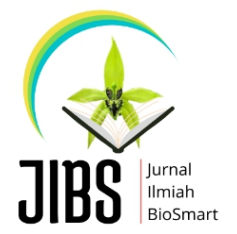

JURNAL ILMIAH BIOSMART (JIBS)

Volume 1, Nomor 1

p-ISSN: 2356-1823

https://jurnal.fkip.unmul.ac.id/index.php/biosmart

sehari semalam dalam jangka waktu seminggu. Pemasangan alat penangkap ikan (bubu) diletakan di tiga lokasi yakni bagian hulu, tengah dan hilir sungai. Sebelum meletakkan bubu terlebih dahulu diisi dengan umpan jeroan ikan yang diletakkan ke dalam bubu. Pengamatan dilakukan pada pagi hari dan membuat daftar ikan yang diperoleh setiap hari. Hamabatan dalam menggunakan perangkap ikan selama penelitian yaitu hujan di malam hari yang menyebabkan bubu hanyut dan tidak mendapatkan ikan di hari tersebut. Selain dilakukan dengan cara meletakkan alat perangkap ikan, penangkapan ikan dilakukan juga dengan menjala, dan memancing di sungai. Kemudian ikan yang diperoleh selanjutnya dikumpulakan dan dikelompokkan berdasarkan jenisnya. Hasil perhitungan jumlah ikan di seluruh stasiun, selanjutnya ditabulasikan ke dalam tabel berikut ini:

Tabel 1. Jumlah Ikan yang diperoleh di Sungai Lempake Tepian Selama Penelitian

\begin{tabular}{clcc}
\multicolumn{3}{c}{ (ekor) } & \multicolumn{1}{c}{ Ordo } \\
\hline No & \multicolumn{1}{c}{ Jenis Ikan } & Cypriniformes & 35 \\
\hline 1. & $\begin{array}{l}\text { Sepat } \\
\text { (Trichopodus trichopterus) }\end{array}$ & Perciformes & 15 \\
\hline 2. & Nila (Oreochromis niloticus) & Anabantiformes & 63 \\
\hline 3. & Seluang (Rasbora spp) & Anabantiformes & 41 \\
\hline 4. & Puyau (Osteochilus hasselti) & Siluriformes & 58 \\
\hline 5. & $\begin{array}{l}\text { Ikan Sapu-sapu (Hypostomus } \\
\text { plecostomus) }\end{array}$ & & \\
\hline
\end{tabular}

Berdasarkan tabel 1, ikan yang diperoleh selama proses penelitian sebanyak 5 spesies yakni ikan sepat ( 35 ekor), ikan nila (15 ekor), ikan seluang (63 ekor) ikan puyau (41 ekor) dan ikan sapu-sapu (58 ekor). Ikan yang diperoleh dalam jumlah sedikit yakni ikan nila sebanyak 15 ekor. Berikut ini grafik jumlah spesies dan populasi ikan di Sungai Lempake Tepian selama proses penelitian. 


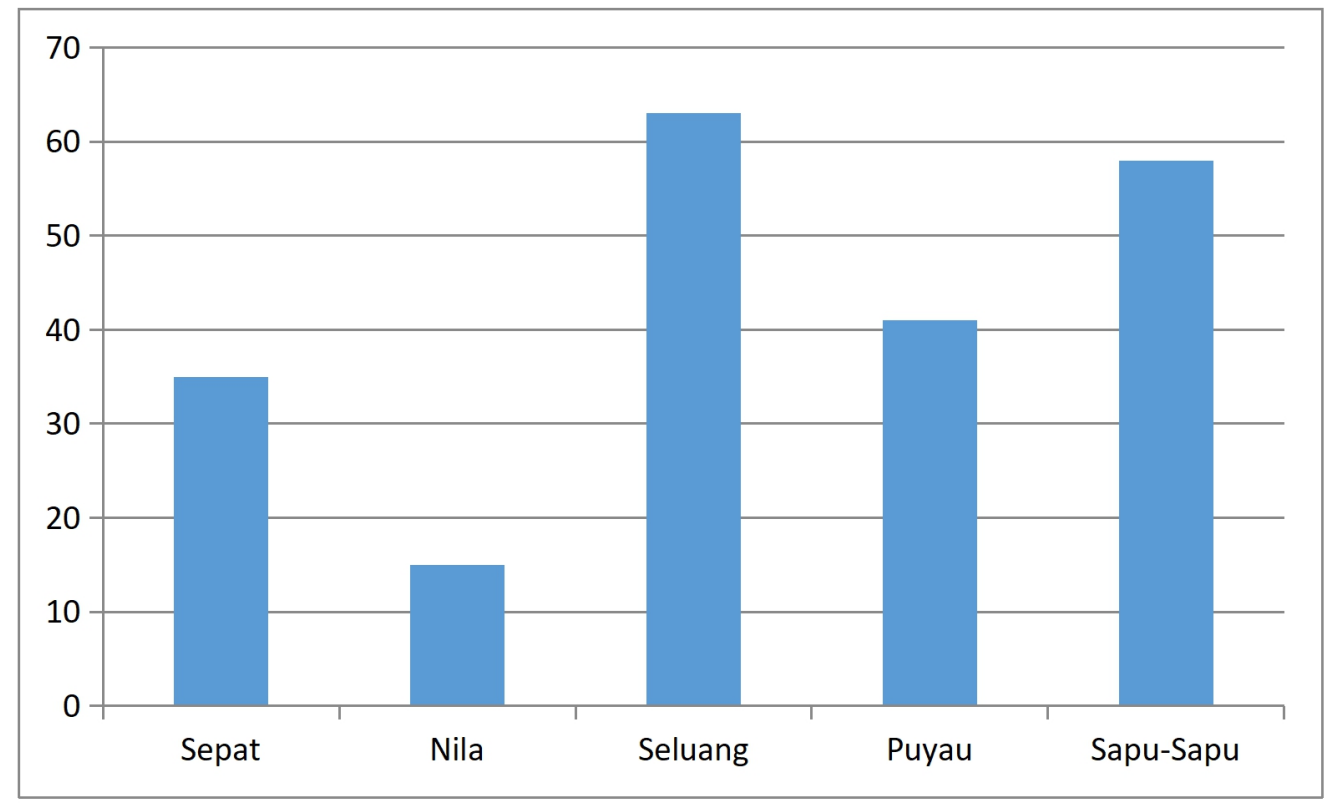

Gambar 1. Populasi Spesies Ikan di Sungai Lempake Tepian (Tahun 2020)

Berdasarkan hasil pengamatan ikan sepat mempunyai ciri-ciri diantaranya bentuk tubuh pipih memanjang, ukuran $3-7 \mathrm{~cm}$, mempunyai sisik yang tipis, ikan sepat yang masih kecil memiliki warna putih keperakan dan di dua sisi tubuhnya terdapat garis berwarna kehitaman. Ikan nila juga ditemukan di Sungai ini, ukuran ikan yang ditemukan sekitar 5-10 cm. Warna tubuh kehitaman atau keabuan, bentuknya pipih dan berukuran kecil hingga sedang. Ikan ini banyak dikonsumsi dan mempunyai rasa yang gurih dan sangat disukai oleh masyarakat karena mempunyai rasa yang khas. Ikan seluang mempunyai ciri-ciri memiliki bentuk tubuh pipih memanjang dengan sisik tipis. pada seluang yang masih kecil memiliki warna putih keperakan dan di dua sisi tubuhnya terdapat garis berwarna kehitaman. di saat mereka telah tumbuh dewasa, warna ini memudar digantikan warna putih kekuning-kuningan. Ikan puyau mempunyai ciri-ciri bentuk anterior agak lonjong dan bagian posteriornya lebih pipih. Pada bagian kepala mempunyai ukuran yang lebih besar dari bagian tubuhnya. Hampir di seluruh permukaan tubuh termasuk kepalanya bersisik kasar dan berukuran agak besar. Jari-jari siripnya keras dari sirip perut dapat digerakkan untuk berjalan di permukaan lumpur yang kering.

Selama proses penelitian tim peneliti dibantu oleh warga yang sehari-harinya bekerja sebagai pencari ikan di sungai. Pengambilan sampel ikan di sungai ini juga 


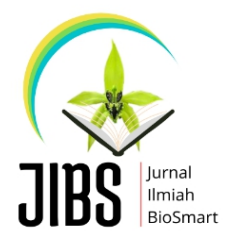

JURNAL ILMIAH BIOSMART (JIBS)

Volume 1, Nomor 1

p-ISSN: 2356-1823

https://jurnal.fkip.unmul.ac.id/index.php/biosmart

memperhatikan perubahan cuaca kota Samarinda yang pada saat penelitian sering mengalami mendung dan hujan dibulan November-Desember dalam memperhatikan keamanan dan selamatan. Air Sungai Lempake Tepian dalam kondisi berwarna keruh, kuning kecoklatan dan berbau. Sebagian warga di bantaran sungai ini juga memanfaatkan air untuk mandi dan cuci. Di bagian lain warga sudah memanfaatkan air PDAM Tirta Dharma. Selain wawancara aktivitas pengambilan data, tim juga melakukan wawancara terkait dengan perolehn informasi yang dibutuhkan selama penelitian. Di sungai ini sebagian masyarakat Kota Samarinda menangkap ikan dengan cara memancing. Banyak ikan yang diperoleh dari sungai ini menandakan bahwa sungai ini masih menjadi habitat ikan dan biota lainnya. Selain ikan sungai ini menjadi habitat lobster air tawar, keong mas, udang dan lain-lain.

Adanya aktivitas manusia dan aliran sedimentasi yang melewati sungai tersebut menjadi ancaman bagi kehidupan biota, dan tidak menutup kemungkinan di kemudian hari, sungai ini tidak lagi ditemukan ikan maupun biota lainnya. Banyaknya sampah organik dan plastik di tempat itu menyebabkan sungai kelihatan kotor, bewarna keruh dan berbau. Sungai yang berbau biasanya disebabkan adanya alga atau ganggang di perairan dan banyaknya limbah bahan buangan baik padat maupun cair yang terdapat di air sungai. Semakin banyak penduduk yang menempati wilayah tersebut maka semakin banyak bahan buangan sehingga masyarakat dapat menjaga sungai untuk tidak membuang sampah langsung ke sungai. Berikut ini hasil analisis data yang ditabulasikan ke dalam tabel 2.

Tabel 2. Keanekaragamn Jenis Ikan di Sungai Lempake Tepian Samarinda

\begin{tabular}{|l|l|c|l|c|c|c|c|}
\hline No & \multicolumn{1}{|c|}{ Jenis Ikan } & $\mathrm{ni}$ & $\mathrm{N}$ & $\mathrm{KR}(\%)$ & $\mathrm{Pi}$ & $\mathrm{Ln} \mathrm{Pi}$ & $\mathrm{Pi} \mathrm{Ln} \mathrm{Pi}$ \\
\hline 1. & $\begin{array}{l}\text { Sepat (Trichopodus } \\
\text { trichopterus) }\end{array}$ & 35 & 212 & 16.50 & 0.165 & -1.802 & -0.297 \\
\hline 2. & $\begin{array}{l}\text { Nila (Oreochromis } \\
\text { niloticus) }\end{array}$ & 15 & 212 & 7.07 & 0.071 & -2.645 & -0.188 \\
\hline 3. & Seluang (Rasbora spp) & 63 & 212 & 29.8 & 0.297 & -1.214 & -0.361 \\
\hline 4. & $\begin{array}{l}\text { Puyau (Ostheocilus } \\
\text { hasselti) }\end{array}$ & 41 & 212 & 19.33 & 0.193 & -1.645 & -0.769 \\
\hline 5. & $\begin{array}{l}\text { Ikan Sapu-sapu } \\
\text { (Hypostomus } \\
\text { plecostomus) }\end{array}$ & 58 & 212 & 27.35 & 0.273 & -1.298 & -0.354 \\
\hline & Jumlah & 212 & 1060 & 100 & 0.999 & -8.604 & 1.969 \\
\hline
\end{tabular}




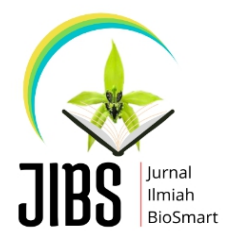

JURNAL ILMIAH BIOSMART (JIBS)

Volume 1, Nomor 1

p-ISSN: 2356-1823

https://jurnal.fkip.unmul.ac.id/index.php/biosmart

Kategori dalam Indeks keanekaragaman Shannon Wienner $\mathrm{H}^{\prime}<1$ maka dapat dikategorikan rendah, $1<\mathrm{H}^{\prime}<3$, dikategorikan sedang dan $\mathrm{H}^{\prime}>3$ dikategorikan tinggi. Berdasarkan kategori tersebut hasil analisis data menunjukkan $1<H^{\prime}<3$, yakni 1.969 , maka dapat disimpulkan indeks keanekaragaman jenis ikan di Sungai Lempake Tepian Kota samarinda dikategorikan sedang. Jumlah total ikan yang diperoleh di di Sungai Lempake Tepian selama penelitian yakni 212, dengan keanekaragaman sebesar 1.969 (kategori sedang). Kemelimpahan relatif ikan seluang (29.8\%), ikan sapu-sapu 27.35\%, puyau (19.33\%), ikan puyau (19.33\%), ikan sepat (16.50\%) dan ikan nila (7.07\%).

Menurut Insafitri (2010) indeks keanekaragaman (H') dapat diartikan sebagai suatu penggambaran secara sistematik yang melukiskan struktur komunitas dan dapat memudahkan proses analisa informasi-informasi mengenai macam dan jumlah organisme. Selain itu keanekaragaman dan keseragaman biota dalam suatu perairan sangat tergantung pada banyaknya spesies dalam komunitasnya. Semakin banyak jenis yang ditemukan maka keanekaragaman akan semakin besar, meskipun nilai ini sangat tergantung dari jumlah inividu masing-masing jenis (Wilhm dan Doris 1986). Pendapat ini juga didukung oleh Krebs (1985) yang menyatakan semakin banyak jumlah anggota individunya dan merata, maka indeks keanekaragaman juga akan semakin besar. Indeks keanekaragaman ( $\left.\mathrm{H}^{\prime}\right)$ merupakan suatu angka yang tidak memiliki satuan dengan kisaran 0 - 3. Tingkat keanekaragaman akan tinggi jika nilai H' mendekati 3, sehingga hal ini menunjukkan kondisi perairan baik. Sebaliknya jika nilai H' mendekati o maka keanekaragaman rendah dan kondisi perairan kurang baik (Odum, 1993).

Perhitungan keseragaman (e) pada hasil penelitian ini diperoleh dari H' dibagi dengan $\mathrm{H}$ maksimum (jumlah spesies). Keseragaman (e) ikan di Sungai Lempake Tepian Kota samarinda berdasarkan hasil penelitian dan analisis data sebesar 0.394 dikategorikan sedang, serta indeks Dominansi (D) jenis ikan di Sungai Lempake Tepian Kota Samarinda sebesar 0.04 sehingga dapat disimpulkan tidak diperoleh spesies yang mendominasi.

Odum (1996) menyatakan keanekaragaman identik dengan kestabilan suatu ekosistem, yaitu jika keanekaragaman suatu ekosistem relatif tinggi maka kondisi 


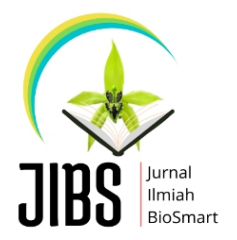

JURNAL ILMIAH BIOSMART (JIBS)

Volume 1, Nomor 1

p-ISSN: 2356-1823

https://jurnal.fkip.unmul.ac.id/index.php/biosmart

ekosistem tersebut cenderung stabil. Lingkungan ekosistem yang memiliki gangguan keanekaragaman cenderung sedang, pada kasus lingkungan ekosistem yang tercemar keanekaragaman jenis cenderung rendah (Riskawati, 2013). Keanekaragaman spesies memiliki dua komponen utama yaitu kekayaan spesies (species richness) dan kelimpahan relatif (relative abundance). Sehingga keanekaragaman spesies dalam suatu komunitas sangat berkaitan dengan kelimpahan spesies tersebut dalam area tertentu. Selain itu, keanekaragaman spesies merupakan suatu karakteristik ekologi yang dapat diukur dan khas untuk organisasi ekologi pada tingkat komunitas. Keanekaragaman spesies suatu komunitas terdiri dari berbagai macam organisme berbeda yang menyusun suatu komunitas. (Campbell, 2010).

\section{Kesimpulan}

Berdasarkan hasil penelitian keanekaragaman jenis ikan di Sungai Lempake Tepian Kota Samarinda (H) 1.969 dikategorikan sedang, kemelimpahan relatif (KR) ikan seluang (29.8\%), ikan sapu-sapu 27.35\%, puyau (19.33\%), ikan puyau (19.33\%), ikan sepat (16.50\%) dan ikan nila (7.07\%). Indeks keseragaman (e) sebesar 0.394 dikategorikan sedang dan indeks Dominansi (C) sebesar 0.04.

\section{DAFTAR PUSTAKA}

Afriani, dkk. 2020. Pengetahuan dan Perilaku Masyarakat Terhadap Pentingnya Ruang Terbuka Hijau di Sempadan DAS Karang Mumus. Jurnal Penelitian Geografi. Vol. 8. No. 1. Halaman 71.

Alamsyah, Sujana. 2006. Merakit Sendiri Alat Penjernih Air untuk Ruma Tangga. Jakarta: Kawan Pustaka. Hal. 8

Erwin, Lilly T. 2011. 25 Cita Rasa Ikan Gurame. Gramedia Pustaka Utama: Jakarta. Halaman 5.

Gleick, Peter H and Meena Palaniappan. 2010. Peak Water Limits to Freshwater Withdrawal and Use. PNAS: Terjemahan.

Insafitri dkk (2010). Keanekaragaman, Keseragaman dan dominansi Bivalvia di Area Buangan Lumpur Lapindo Muara Sungai Porong. Jurnal Kelautan: Indonesian 


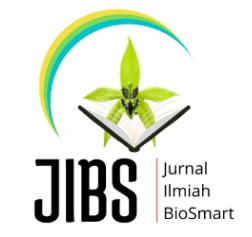

JURNAL ILMIAH BIOSMART (JIBS)

Volume 1, Nomor 1

p-ISSN: 2356-1823

https://jurnal.fkip.unmul.ac.id/index.php/biosmart

Journal of Marine Science and Technology. Jilid 3. Terbitan 1. Hal 54-59. Tanggal 22 April 2010

Kodoatie, Robert. J dan Roestam, S. Tata Ruang Air. 2010. Yogyakarta: CV Andl Offset (Penerbit ANDI). Hal. 1

Juwono, Pitojo. A dan Aris, S. 2019. Integrasi Pengelolaan Daerah Aliran Sungai dengan Wilayah Pesisir. Malang: UB Press. Hal. 15-16

Mukti, dkk. 2017. Penyuluhan Hukum Terhadap Akibat Hukum Pencemaran Lingkungan Sungai Karang Mumus di Kelurahan Sungai Dama. Jurnal Abdimas Mahakam. Vol. 1. No. 1. Halaman 28

Murdiati, dkk. 2013. Panduan Penyiapan Pangan Sehat Untuk Semua. Kencana: Jakarta. Halaman 77.

Riskawati Nento dkk (2013), Kelimpahan, Keanekaragaman dan Kemerataan Gastropoda di Ekosistem Mangrove Pulau Dudepo, Kecamatan Anggrek, Kabupaten Gorontalo Utara. Nikè: Jurnal Ilmiah Perikanan dan Kelautan. Volume 1, Nomor 1, Juni 2013

S.D. Kusumaningsari, B. Hendrarto, Ruswahyuni. 2015. Kemelimpahan Hewan Makrobentos pada umur Tanam Rhizophora sp di Kelurahan Mangunharjo Semarang. Manajement of Aquatic Resources Jurnal (MAQUARES) Vol 4, No 2, pp 58-64, Apr 2015. https://doi.org/10.14710/marj.v4i2.8528 